\title{
English Language Learning Clubs: A Novel Approach to Improving EFL Students' Verbal Communication Skills
}

\author{
Coffi Martinien ZOUNHIN TOBOULA* \\ Laboratoire du Groupe de Recherche sur l'Afrique et la Diaspora (GRAD) Département d'Anglais /FLLAC/ \\ Université d'Abomey-Calavi (UAC)
}

*Corresponding Authors: Coffi Martinien ZOUNHIN TOBOULA, Laboratoire du Groupe de Recherche sur l'Afrique et la Diaspora (GRAD) Département d'Anglais /FLLAC/ Université d'AbomeyCalavi $(U A C)$

\begin{abstract}
This empirical research study investigates the benefits of English-language learning Extracurricular Activities (ECAs) systems. It tried to explore the impact of English Language Learning Clubs (ELLCS) on the Anxiety and Oral Communication Skills (AOCS) of one hundred and thirty (130) intermediate English as a Foreign Language (EFL) learners selected at random from four high schools in Benin. The findings showed that those learners, who previously did not have access to such activities, enhanced both self-assurance and oral communication skills (OCS) by participating in English Language Learning Communities for six months. Based on those findings, this research discussed the importance of ECAs' educational practices in EFL teaching. It advocated for policies that encourage English Language Learning Clubs to develop EFL learners' speaking skills.
\end{abstract}

Keywords: EFL Learners, ECAs, ELLCs, OCS

\section{INTRODUCTION TO THE STUDY}

This research analyses the anxiety control of Beninese intermediate $\mathrm{EFL}^{1}$ learners and the improvement of their oral skills after they participate in English-related Extracurricular Activities (ECAs), such as English Language Clubs. Tallon's (2013, p.5) ${ }^{2}$ theoretical perspective, the notion of some other researchers, including Spolsky (1989, p.166), and the researcher's personal experience in teaching and learning the English language serve as the foundation for this paper. However, learning English is not a mere undertaking. To acquire a solid command of this international language, the student must practice it every day in an atmosphere that can mirror native speakers. Consequently, in various non-English speaking nations, several organisations, clubs, or after-school programs dedicated to studying the English language have evolved to help students and lovers of Shakespeare's language strengthen their language skills.

Therefore, English Language Learning Clubs (ELLC) in Benin have become learning crucibles to practice English successfully. Those who engage in them are often learners of all kinds, including high school students, graduate students in English studies, postgraduate students in other academic training, civil servants, executives, businesspersons, etc.

The concept of English learning clubs arises because studying a foreign language on an individual basis is quite tricky. EFL learners do not frequently have enough opportunities to practice their new language in class. Some occasionally meet regularly in groups of friends or learners from school programs to improve their language skills. There are learning circles where learners may have the opportunity to experience one-on-one or group talks with their fellow mates without worry. Learning their target language becomes more straightforward and fascinating than ever when joining learner groups to share the same issues and interests.

Learners benefit from these language-learning circles because they provide a friendly and calm learning environment. They are educational environments in which students receive feedback and

\footnotetext{
${ }^{1}$ EFL : English as a Foreign Language

2 "More exposure to the target language, outside of the classroom, may help anxious students become more comfortable with the language and thus help reduce the anxiety" (Tallon, 2013, p.5).
} 
support themselves in improving their language skills. They help individuals in acquiring confidence. They learn to strengthen their leadership abilities by adopting diverse roles in the various activities they handle in these language-learning clubs. Some of these learning activities are role-playing, speaking and listening, debates and discussions, reading comprehension, games, presentations, conversation with native speakers, immersion trips to countries using English as a first language, theatre, films, and viewing videos.

However, thus far, only a little research has evaluated the efficiency of these educational programs' teaching methods. Therefore, the current study proposes to analyse the effects of these English-related extracurricular activity systems on Beninese EFL learners' language skills through empirical research.

Several studies looked into how to deal with Foreign Language Anxiety (FLA). However, there are currently few findings on the best approach to combat students' anxiety, which affects their motivation to learn and speak the target language well. Because of their limited interaction with native speakers and the absence of chances to practise English in their daily lives, English as Foreign Language (EFL) learners in Benin have always found learning English difficult. Furthermore, the time allowed for English instructors to teach the language ( 2 to 4 hours per week) does not permit them to dedicate enough time to oral communication instruction or extracurricular activities to practice the language with their students. Furthermore, only a tiny proportion of EFL students stay connected to English outside of the classroom, making it difficult for them to stay motivated to study English, which they see as just a compulsory school subject (Ho, 1998, cited in Liu, 2012, p.123). They do not have a comfortable setting for interaction outside of their classroom. Thus, they have no chance to expose themselves to adequate English language impacts from the outside. As a result, after years of English language instruction, they still fear speaking the language. The absence of such a languagelearning environment may easily explain why English immersion programs in language training facilities are so effective and why Beninese individuals want to go overseas to improve their English speaking skills.

In light of the two aims mentioned above, the current research seeks to address the following questions:

1) Is there a correlation between Beninese intermediate EFL learners' engagement in English Language Learning Clubs and their ability to manage their Foreign Language Anxiety?

2) To what extent can language-focused ECAs programs, such as English Language Learning Clubs, contribute to developing Beninese intermediate EFL learners' capacity to communicate in English?

This research assumed that speaking a foreign language is the primary source of worry. Therefore, instructors should encourage distraught students to engage in additional learning, such as joining a language-related extracurricular activity. As a result, the analysis of corresponding literature established that the learner has several options for language learning club activities that may assist her/him in managing her/his anxiety.

Thus, to carry out a credible study, the present study tested the following assumptions:

a) Participating in language-related extracurricular activities might help alleviate the anxiety of Beninese Intermediate EFL students.

b) English Language Clubs can significantly improve the speaking abilities of Beninese EFL Intermediate students.

This research is crucial because its findings will assist EFL/ESL instructors in resolving shyness, passiveness, and concerns that inhibit learners from speaking English successfully. Additionally, it will help learners feel more comfortable communicating in English with people they trust, have fun discussing current events. Finally, it will broaden their horizons regarding English culture and expand their linguistic competence, interpersonal skills, public speaking, leadership, critical listening skills, competencies, and abilities to perform well on oral and written tests. 


\section{REVIEW OF RELATED LITERATURE}

Oral skill development in a foreign language environment has always been a significant barrier for learners who, it seems, overlook their value due to the fear they feel while attempting to speak the target language. As Celce-Murcia (1991, p.125) notes, "it has become [clear] in recent years that [the aim] of language education programs [has shifted significantly]." Nowadays, productive language learners are those that are capable of communicating successfully in a second or foreign language. In contrast, two decades ago, the correctness of the language generated was almost certainly the primary factor used to determine a student's success or failure (Cf. Riggenbach and Lazaraton, 1987 edited in Celce-Murcia, 1991, p.125). Speaking in a second or foreign language (L2/FL) has held an unusual position throughout most of the history of language instruction. It started evolving as a distinct area of teaching, learning, and assessing in its own right, hardly focusing on the yielding of spoken discourse (Bygate, 1987, p.14). It has [become more than essential and] arisen as a distinct field of language education in recent years (Bygate, 1987, p.15).

The fear of learning a foreign language, on the other hand, is essential since it may denote an emotionally and physically distressing feeling for some learners; if learners are excessively nervous in class, they are likely not wholly focused or interested at all (Tallon, 2008, p.2). Horwitz et al. (1986, p. 128) describe it as "a distinct complex of self-perceptions, beliefs, [attitudes], and behaviour [associated with] classroom language learning [that results] from the [process' distinctiveness]" (Cf. Wang, 2009, p.20).

The learners' requirements and interests determine the language learning process. As Cook, Long, and McDonough (1979) stated, "when there is a [true] purpose [for] the foreign language in the curriculum, the L2 learner is not [just acquiring] new syntax and vocabulary, but also [acquiring the ability to operate] in the new language" (para.10). Husni (2005), who asserts, "Input [provides] the raw materials [necessary for language learning to occur]" (p.63), corroborates this view.

Cook, Long, and McDonough (1979) argued that "a [youngster acquiring] his first language is [plainly acquiring more than linguistic] forms [...]; his language is [implicated in his growing] cognitive structure, emotional states, relationships, and play" (para.8). They said, "The same [assertion] will [inevitably] be true of [most] second language learning in a 'natural [context],' and 'the learner's language reflects his own needs and interests, [even if they vary from those of the youngster]" (para.13). In other words, the mechanism of learning a new language should be identical to that used to acquire the first one; this raises the issue of the learning setting.

According to Husni (2005, p.64), a setting is a geographical area and period during which language learning occurs. He cited Littlewood (1984, p.15), who stated that "in a behaviourist approach to language acquisition, the infant's] environment [has a significant impact on the target language acquisition by providing] both models [for the kid to copy and incentives for learning]" (p.64). He (Husni, 2005) then distinguished between settings: conventional classroom settings and natural outdoor settings. Husni (2005) elaborated on these two types of settings. He stated, "L1 is [acquired] by the child in a natural [environment], [whereas] L2 is [usually learned] in a formal setting" (Husni, 2005, p.65). He added that "[natural context allows] the child to acquire the language freely and without [fear of failure]" (2005, p.66). On the other hand, he noted that "the [environment in which] L2 acquisition [occurs is generally] formal" and that "this [environment leads] the learner [to] feel [moody, anxious, or worried]" (Ibid.).

As observed in Husni (2005), Littlewood (1984, p.97) "[states] that [...] anxiety [may impede] learning [in the classroom and make learners hesitant] to express themselves [in] the L2" (2005, p.66). According to Husni (2005, p.66), "we should [...] avoid becoming [excessively critical] of students' performance". We should instead attempt "[...] to create space for each learner's individuality to express itself, [and] work to [create] a relaxed classroom atmosphere with cooperative relationships" (2005, p.66).

On the other side, Littlewood $(1984$, p.91) suggests, "Almost our [entire] teaching effort should be directed toward creating contexts for language use in the classroom [...]" (As observed in Husni, 2005, p.66). The language may be used through listening and reading activities, discussion, communication tasks, role-playing, or contexts that approximate learning in a natural environment. 
The fundamental properties of learning in a natural setting that approximates learning through ECAs in an EFL context contribute to developing three concurrent adult functions identified by Halliday (1975). First, there are "the interpersonal (relating to people), the ideational (communicating ideas to other people), and the textual (relating one piece of language to another)" (As observed in Cook, 2010, p.145). Second, Husni (2005, p.66) claimed that "these contexts [for language learning through ECAs] should [allow] learners to [form] their representations of the language in the same [manner] they would in a natural [setting] and [follow] the same [developmental sequences] as a natural learner."

Various research studies have revealed that involvement in extracurricular activities improves learners' academic achievement (Fujita, 2006, para.5). According to Reva (2012), "there is an [widespread] agreement in [...] applied linguistics and education [...] to [promote] extracurricular activities in university programs for students [of various] majors [...]" (p.1). This researcher argued, "[...] Extracurricular Activities (ECAs) help [students] develop [critical] skills such as leadership, [socialisation], and character training [...]" (Reva, 2012, p.1). Several studies have investigated this issue. However, relatively few have examined its effect on developing speaking ability and the treatment of language anxiety.

Extracurricular Activities (ECAs) are recreational activities that take place outside of the classroom. They are all social and educational activities that are not part of the academic curriculum but help students develop their knowledge in a particular domain. Campbell (1973, referenced in Reva, 2012, p.1) describes them as "[students'] activities that fall outside the [conventional] curriculum of an educational institution; they [complement] the [usual] course of classroom [teaching] and are sometimes [arranged] or [performed] with some [teacher engagement]."

Nowadays, several foreign language students worldwide engage in a range of Extracurricular Activities (ECAs) with the hope of developing a solid command of their target language. While many EFL learners in Benin claim to have improved their speaking ability by participation in ECAs, a sizable proportion of learners and instructors remain sceptical about the beneficial effect such activities may have on English learning. It is then necessary to shed light on the educational value of those programs through empirical research to encourage EFL students to learn the most of them. It is also vital to assist EFL/ESL teachers in improving and expanding their learners' prior knowledge of the language and acclimating to various strategies that result in more lively and relaxed classes.

\section{Methodology Of The Study}

\subsection{Selection of the Research Sites}

The research study took place in eight of the twelve territory departments that presently comprise the Republic of Benin after the reform of the territorial administration enacted by Law No. 97-028 of January 15,1999 , on the structure of the Republic of Benin's territorial administration ${ }^{3}$. These eight territorial departments are divided into four geographic regions: Atlantique-Littoral (AL) in the south, Ouémé-Plateau (OP) in the southeast, Mono-Couffo (MC) in the south-west, and Borgou-Alibori (BA) in the north. The carrying out of this study in those four geographic locations can be explained by the fact that those areas are home to the most well-known English language clubs managed by some language teachers and EFL learners to help English language learning. As a result, data for this research were gathered from four public secondary schools (each from one of the four geographical areas mentioned above).

\subsection{Participants}

The study sampled 130 intermediate EFL students randomly selected from four secondary schools. Each school divided these students into two groups. One group (consisting of 65 EFL students) served as the experimental group, while the other (consisting of the remaining 65 EFL students) served as the control group. These participants were intermediate EFL students in the lower sixth and upper sixth grades (Première and Terminale in the French educational system). They had never participated in

\footnotetext{
${ }^{3}$ For further information on the reform of the Republic of Benin's territory administration, see Guide Juridique de la Réforme de l'Administration Territoriale, Tome 1 : Loi, N. 97-028 portant organisation de l'administration territoriale de la République du Bénin; 1999.
} 
language-related Extracurricular Activities (ECAs). They were all one-time students at those two grade levels. The experimental group consisted of 42 (64.61\%) males and 23 (35.39\%) females; the control group consisted of 43 men (66.15\%) and 22 females (33.85\%). Table 1 below presents the distribution of the subjects' population of the four secondary schools selected throughout the country.

Table1. Distribution of learners' population in both groups (experimental and control)

\begin{tabular}{|c|c|c|c|c|c|c|c|}
\hline \multirow{2}{*}{$\begin{array}{l}\text { Research sites } \\
\text { (Geographical areas) }\end{array}$} & \multirow[t]{2}{*}{ School's name } & \multicolumn{2}{|c|}{$\begin{array}{l}\text { Experimental } \\
\text { Group }\end{array}$} & \multicolumn{2}{|c|}{$\begin{array}{l}\text { Control } \\
\text { Group }\end{array}$} & \multicolumn{2}{|c|}{$\begin{array}{l}\text { Number of } \\
\text { Participants from each school }\end{array}$} \\
\hline & & Boys & Girls & Boys & Girls & Boys & Girls \\
\hline $\begin{array}{l}\text { Altantique- } \\
\text { Littoral (AL) }\end{array}$ & CEG Godomey & 9 & 4 & 14 & 6 & 13 & 20 \\
\hline Ouémé-Plateau (OP) & CEG Agbokou & 8 & 7 & 6 & 8 & 15 & 14 \\
\hline Mono-Couffo (MC) & CEG 2 Lokossa & 15 & 8 & 11 & 5 & 23 & 16 \\
\hline Borgou-Alibori (BA) & CEG Hubert MAGA & 10 & 4 & 12 & 3 & 14 & 15 \\
\hline Total & & 42 & 23 & 43 & 22 & 65 & 65 \\
\hline
\end{tabular}

Only the sixty-five (65) experimental group learners participated in implementing the English Language Club educational program.

\subsection{Instruments}

To achieve the first and second objectives of this study, a customised test assessing Foreign Language Anxiety (FLA) from Horwitz et al. (1986)'s Foreign Language Classroom Anxiety Scale (FLCAS) and an English Language Assessment Test from Mewald et al. (2012)'s E8 Standards Speaking Test, were developed. Along with those measures, he used semi-structured interview questionnaires, focus groups, and observations of English language clubs to delve further into the English Language Clubs' effects on the 65 intermediate EFL learners who participated in those English-related ECAs for six months.

To create the Foreign Language Anxiety Test (FLAT) applied in this study, the 33 multiple-choice questions developed by Horwitz et al. (1986) were slightly revised to make them more relevant to the Republic of Benin's foreign language anxiety issues.

* Among the FLCAS's 33 questions, 24 are negatively phrased to elicit agreement (or strong agreement) from students with higher language anxiety. The other nine questions $(2,5,8,11,14$, $18,22,28$, and 32) are phrased favourably to elicit disagreement (or strong disagreement) from students who have less language anxiety. For negative assertions, selecting "Strongly Agree" earns 1 point, while selecting "Strongly Disagree" earns 5 points. When the statements are positively formulated, the points are inverted. Thus, the option of "Strongly Agree" earns 5 points, whereas "Strongly Disagree" earns 1 point. Thus, the probable output ranges between 33 and 165 for this instrument of analysis. Similarly, a high score (for example, "165") indicates a low amount of anxiety, while a low score (for example, "33") indicates a high degree of language anxiety. The Foreign Language Anxiety Test (FLAT) was implemented to assess foreign language anxiety among EFL learners using a questionnaire-based approach.

Many researchers (Aida, 1994; Chang, 1999; Ganschow et al., 1994; Ganschow \& Sparks, 1996; Liao, 1999) addressed the value of this tool. As observed in Chan and Wu (2004), this foreign language anxiety instrument "has been widely adopted by a large number of researchers to investigate learners' foreign language anxiety" (p.292) due to its validity and reliability.

* Given that the E8 Standards Speaking Test was developed to "encompass levels A2 to B1 in the Common European Framework of Reference (CEFR)" (Mewald et al., 2012, p.35), and because of the context of the present study, it was primordial to expand it by designing the E10 Standards Speaking Assessment Test. Therefore, this study incorporates the levels A2 to B2 in the CEFR by assessing ten speaking standards. This 'E10 standards' speaking assessment examination, like the $\mathrm{E} 8$, is meant to be administered by competent examiners to pairs of test-takers (EFL learners). Therefore, it is divided into three sections:

- Section 1 ("Warm-up"): The test takers acquainted themselves with examiners

- Section 2: Every test taker delivers a monologue based on verbal or visual prompts. 
- Section 3: The two examinees engage in a dialogue built on both verbal and visual incentives.

Examiners utilise standardised improvement questions to help participants stay on track and avoid long pauses. Test takers' strengths and weaknesses in oral communication are measured by having them complete a language assignment with no preparation and in an environment similar to their age group's actual language usage. It took 15 minutes to complete the assignment (Section 1: 3 minutes; section 2: 5 minutes, and section 3: 7 minutes).

\subsection{Procedures and Statistical Measures used to analyse the collected Data}

The data from the study were input into and analysed using a computer software program ( $\left.\operatorname{SPSS}^{4} 26\right)$. The keywords approach was used to examine the data gathered from the semi-structured interview questions (Keywords were extracted from the qualitative questions, entered on SPSS charts as texts, and the frequencies of entries were calculated). The respondents' beliefs and attitudes toward the concept of managing foreign language anxiety and developing speaking ability through participation in English-related extracurricular activity programs were gathered through semi-structured interviews, focus groups, and observations at English Language Clubs. All 130 Intermediate EFL students (in both the experimental and control groups) were pre-tested on their primary anxiety level and oral communication standard before the study began. They were assessed using two separate instruments: the Horwitz (1986)-adapted Foreign Language Anxiety Exam (FLAT) and the E10 Standards Speaking Assessment test explicitly designed for the present study. Learners in the experimental group were only those who took part in the English Language Club' programs. Students in the control group were taught oral communication using the traditional method. Both experimental and control groups were post-tested on their anxiety levels and spoken communication abilities at the end of the six-month experiment. This measure was to examine whether they had improved their self-confidence and speaking ability skills in the meanwhile.

\section{Presentation, Analysis, And Discussion Of The Results}

\subsection{Presentation, Analysis, and Interpretation of the Findings}

\subsubsection{Interviews}

The participants in this survey were chosen at random with the assistance of several of their English language professors. They completed an open-ended questionnaire before and after the experiment through semi-structured interviews. All respondents to the study during the pre-test offered identical responses. They have all admitted that they have never been exposed to a language-focused ECA before. The primary language skill that they wish to enhance is their oral communication skills.

Indeed, while $2.30 \%$ stated that they needed to improve their reading skills and $3.84 \%$ said they needed to improve their listening skills, the vast majority (93.86\%) indicated they needed to improve their speaking talents. Additionally, the likelihood of a person having a Chi-square of $(0.000)$ was less than $1 \%$. This observation shows a high correlation between learners' English proficiency and the language skills they most need to acquire.

None of the EFL participants in the survey said that they were happy with the various speaking practices they engaged in, in class. On the contrary, the majority stated that they were dissatisfied, and only a handful indicated that they were slightly satisfied. This observation shows that English classroom activities alone are insufficient to enable learners to increase their English ability.

The majority of individuals in the experimental group and those in the control group expressed themselves in unstructured English during the pre-test interview on their Foreign Language Anxiety level and verbal communication ability. For instance, one of them (from the experimental group) stated the following: "My name is Codjo, I have 18 years old, and I am doing the final year at school". Furthermore, "I like to learn language like English and Spanish, but it is difficult for me to understand the two."

\footnotetext{
${ }^{4}$ SPSS, or "Statistical Package for the Social Sciences," is a commonly used software tool for statistical data analysis in the social sciences. SPSS, Inc. was the firm that created the program, but IBM purchased it in 2008. The software program was renamed to PASW (Predictive Analytics Software) during the transfer; however, it has now been reverted to SPSS again. (Using SPSS and PASW, 2018, September 24)
} 
Surprisingly, following a six-month experiment, the experimental group's English language production quality improved, while the control group remained unchanged. When reviewing the background information provided by all study participants during their initial interview, it was noticed that most of those in the experimental group, in comparison to the control group, were able to speak more fluently than the first time (as illustrated above). They also responded differently to the same questions in terms of English language syntax. For instance, the reply "Codjo" stated, "My name is Codjo, and I am 18 years old." "I am in the upper sixth grade and am interested in learning languages such as English and Spanish [...]". The data collected from their experiences with the English-related ECA program (English Language Clubs) revealed the following implicit beliefs: They believe that the program facilitates learning and provides a positive and supportive learning environment to secure practical knowledge and a commitment to self-development. The majority of them stated that it considerably helps them manage their fear while speaking in front of an audience. As a result of this instructional program, some others made the following statement "I acquired confidence and therefore enhanced my ability to speak English as a foreign language in front of a large group of people."

\subsubsection{Focus Groups}

Focus groups were performed with experimental group participants to elicit more information about the English Language Clubs program's efficacy in language acquisition. The 65 respondents in the experimental group were divided into five subgroups to induce their opinions on the usefulness of this teaching strategy for language learning. The first group included 13 students ( 9 men and 4 females), the second comprised 15 students ( 8 men and 7 females), the third consisted of 11 students ( 7 males and 4 females), the fourth included 12 students ( 8 males and 4 females), and the fifth had 14 students (10 males and 4 females).

When asked about how they would define the programs of English Language Clubs, the majority of participants in each focus group stated that an English Language Club is a facilitative program that assists learners in developing oral communication and leadership abilities. Several of them noted the following about the program's benefits: "English Language Clubs assist learners in improving their pronunciation, listening, and speaking abilities. Additionally, they assist kids in developing more selfconfidence". "From my experience with this program, I can attest that it is a method of teaching that assists students in overcoming their fear of speaking in front of an audience."

To the question, "What English language skills have you improved as a result of your involvement in English Language Clubs?" the majority of participants stated that they increased both their oral communication abilities. They also mentioned that they developed self-confidence because of their engagement in English Language Clubs. Several participants reported that they had improved their ability to handle their nervousness when speaking in front of an audience. "English Language Clubs taught me how to utilise precise phrases that convey what I mean exactly," they remarked. Some added, "By using short phrases, I find it simpler to communicate and be understood." "English Language Clubs facilitated the development of my listening and speaking abilities. I gained greater self-confidence and broadened my knowledge of personal growth as a result of this program".

\subsubsection{English Language Clubs Observations}

During the six-month experimental period, several English Language Club observations were performed to determine the experiment group members' views about the English-related ECA program under investigation. Each week, the activities of one English Language Club session were videotaped. These English Language Club observations or activity videorecordings occurred in each of the experiment's four geographical zones (AL, OP, MC, and BA).5. The following points were stressed throughout the observations: 1) The activities undertaken; 2) The duration of meetings; 3) The learners' emotions and attitudes; 4) The environment's atmosphere, and 5) The moderators' duties. The present research work presents and analyses only one of the numerous observations made in each of the four English Language Clubs settings based on the four geographic regions (See Table 2 below).

Table2. Presentation and analysis of the classroom observations collected from each of the four English Language Clubs settings located in the four geographical areas where the experimentation took place English Language Club observation English Language Club observation 
English Language Learning Clubs: A Novel Approach to Improving EFL Students' Verbal Communication Skills

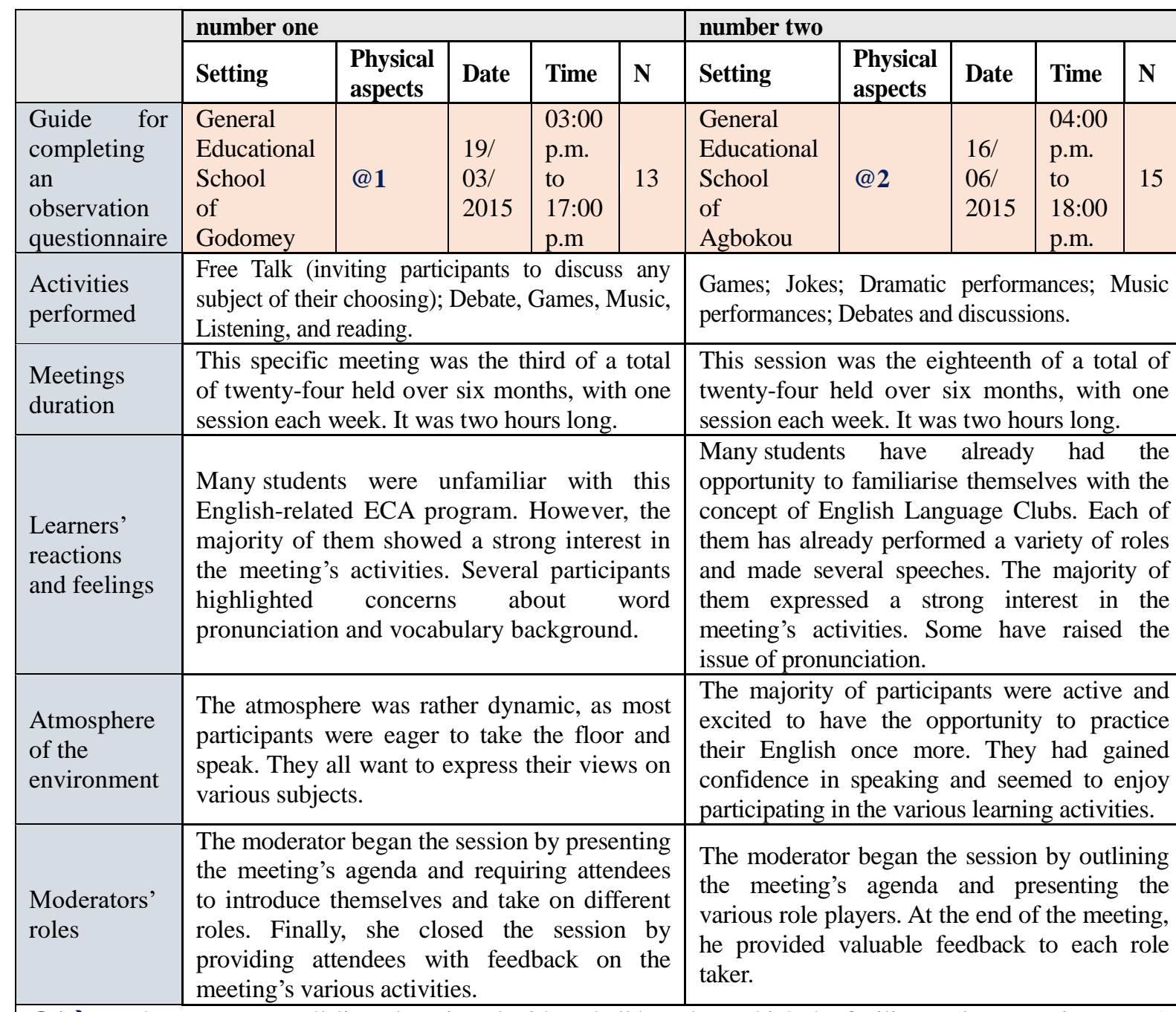

@ $1 \rightarrow$ The room was well-lit and equipped with a chalkboard on which the facilitator (language instructor) scribbled the session's agenda. The room's tables and chairs were moved to create a horseshoe shape. As a lectern, a meter and a half-high table was used. Thus, there was no background noise to detract from the discussion.

@ $2 \rightarrow$ The room was well-lit and equipped with a blackboard on which the facilitator (language instructor) presented the session's agenda. The seats in the room were moved into a horseshoe shape. A table with a height of two and a half meters was utilised as a pulpit. Neither background noise nor other obstacles interfered with the session's progress.

\section{Setting 1: CEG Godomey Setting 2: CEG Agbokou}

\begin{tabular}{|c|c|c|c|c|c|c|c|c|c|c|}
\hline & \multicolumn{5}{|c|}{$\begin{array}{l}\text { English Language Club observation } \\
\text { number Three }\end{array}$} & \multicolumn{5}{|c|}{$\begin{array}{l}\text { English Language Club observation } \\
\text { number Four }\end{array}$} \\
\hline & Setting & $\begin{array}{l}\text { Physical } \\
\text { aspects }\end{array}$ & Date & Time & $\mathbf{N}$ & Setting & $\begin{array}{l}\text { Physical } \\
\text { aspects }\end{array}$ & Date & Time & $\mathbf{N}$ \\
\hline $\begin{array}{l}\text { Guide for } \\
\text { completing } \\
\text { an } \\
\text { observation } \\
\text { questionnaire }\end{array}$ & $\begin{array}{l}\text { General } \\
\text { Educational } \\
\text { School } \\
\text { of Lokossa }\end{array}$ & @3 & $\begin{array}{l}25 / \\
09 / \\
2015\end{array}$ & $\begin{array}{l}03: 30 \\
\text { p.m. } \\
\text { to } \\
17: 30 \\
\text { p.m. }\end{array}$ & 23 & $\begin{array}{l}\text { General } \\
\text { Educational } \\
\text { School } \\
\text { of Hubert } \\
\text { Maga }\end{array}$ & @4 & $\begin{array}{l}15 / \\
11 / \\
2015\end{array}$ & $\begin{array}{l}\text { 03:00 } \\
\text { p.m. } \\
\text { to } \\
\text { 17:00 } \\
\text { p.m. }\end{array}$ & 14 \\
\hline $\begin{array}{l}\text { Activities } \\
\text { performed }\end{array}$ & \multicolumn{5}{|c|}{$\begin{array}{l}\text { Games, jokes, dramatic performances, musical } \\
\text { performances, debates and conversations, and } \\
\text { news presentations were some of the activities } \\
\text { planned for the day. }\end{array}$} & \multicolumn{5}{|c|}{$\begin{array}{l}\text { There were various events scheduled for the day, } \\
\text { including games, jokes, theatrical performances, } \\
\text { musical performances, debates and discussions, } \\
\text { and news presentations. }\end{array}$} \\
\hline $\begin{array}{l}\text { Meetings } \\
\text { duration }\end{array}$ & \multicolumn{5}{|c|}{$\begin{array}{l}\text { This session was the nineteenth of twenty-four } \\
\text { and lasted two hours. }\end{array}$} & \multicolumn{5}{|c|}{$\begin{array}{l}\text { This session was the last of twenty-four and } \\
\text { lasted two hours. }\end{array}$} \\
\hline $\begin{array}{l}\text { Learners' } \\
\text { reactions }\end{array}$ & \multicolumn{5}{|c|}{$\begin{array}{l}\text { All learners have developed a working } \\
\text { knowledge of the English Language Clubs' }\end{array}$} & \multicolumn{5}{|c|}{$\begin{array}{l}\text { Participants displayed a high degree of } \\
\text { engagement in all activities throughout the }\end{array}$} \\
\hline
\end{tabular}




\begin{tabular}{|c|c|c|}
\hline an & $\begin{array}{l}\text { processes. The majority of them expressed a } \\
\text { strong interest in the meeting's activities. They } \\
\text { had gained confidence in speaking and seemed } \\
\text { to enjoy participating in the various learning } \\
\text { sessions. However, several of them expressed } \\
\text { concerns about their pronunciation and } \\
\text { comprehension. }\end{array}$ & $\begin{array}{l}\text { session. They were ecstatic to participate in } \\
\text { the various activities. While some were less } \\
\text { proficient than others, none were hesitant to } \\
\text { take the floor and express their opinions or } \\
\text { participate in the activities. }\end{array}$ \\
\hline $\begin{array}{l}\text { Atmosphere } \\
\text { of the } \\
\text { environment }\end{array}$ & $\begin{array}{l}\text { lout this session, learners were actively } \\
\text { l. }\end{array}$ & $\begin{array}{l}\text { projection activity and awards to the top two } \\
\text { learners chosen outstanding speakers by the } \\
\text { audience. Simply said, there were several } \\
\text { instances of learners actively participating } \\
\text { throughout this session. }\end{array}$ \\
\hline $\begin{array}{l}\text { Moderators' } \\
\text { roles }\end{array}$ & $\begin{array}{l}\text { The moderator began the session by outlining } \\
\text { the day's program and introducing the various } \\
\text { role players. He provided valuable feedback to } \\
\text { each role taker at the end of the meeting. }\end{array}$ & $\begin{array}{l}\text { The facilitator began the session by outlining } \\
\text { the day's program and introducing the various } \\
\text { role players. At the end of the meeting, he } \\
\text { provided valuable feedback to each role taker. }\end{array}$ \\
\hline \multicolumn{3}{|c|}{$\begin{array}{l}\text { @ } \rightarrow \text { The room was adequately lit but somewhat noisy owing to the odd sound made by an old fan. } \\
\text { Although there was no blackboard, the moderator had scribbled the session's agenda on a flip chart. All of the } \\
\text { meeting's attendees sat around a big table. A lectern was positioned in the room's right corner. On a table } \\
\text { was stacked a stack of dictionaries (monolingual and multilingual). } \\
\text { @ } 4 \rightarrow \text { The room was well lit and without noise. The moderator had scribbled the session's agenda on a } \\
\text { chalkboard. The room's tables and seats were rearranged to create a horseshoe. As a lectern, a table about a } \\
\text { meter and a half in height was used. }\end{array}$} \\
\hline \multicolumn{3}{|c|}{ \& $\quad$ Setting 1: CEG Lokossa Setting 2: CEG Hubert Maga } \\
\hline
\end{tabular}

\subsubsection{Results of the Analysis of the Data Collected with the FLAT}

The analysis of data obtained from the experimental and control groups using the Foreign Language Anxiety Test (FLAT) is summarised in Table 3.

\begin{tabular}{|c|c|c|c|c|c|c|c|c|}
\hline \multicolumn{4}{|l|}{ Time } & \multicolumn{2}{|l|}{ Pre-test } & \multirow{2}{*}{ Mean } & \multicolumn{2}{|l|}{ Post-test } \\
\hline Group & Cluster & Gender & Mean & $\begin{array}{l}\text { Std. } \\
\text { Deviation }\end{array}$ & $\mathbf{N}$ & & $\begin{array}{l}\text { Std. } \\
\text { Deviation }\end{array}$ & $\mathbf{N}$ \\
\hline \multirow{15}{*}{$\begin{array}{l}\text { Experimental } \\
\text { group }\end{array}$} & \multirow{3}{*}{$\begin{array}{l}\text { Atlantique- } \\
\text { Littoral }\end{array}$} & Male & .4194 & .03957 & 9 & .5774 & .07244 & 9 \\
\hline & & Female & .4436 & .05782 & 4 & .5076 & .06691 & 4 \\
\hline & & Total & .4268 & .04488 & 13 & .5559 & .07579 & 13 \\
\hline & \multirow{3}{*}{ Ouémé-Plateau } & Male & .4843 & .05348 & 8 & .7027 & .12018 & 8 \\
\hline & & Female & .4898 & .11878 & 7 & .6840 & .07143 & 7 \\
\hline & & Total & .4869 & .08651 & 15 & .6939 & .09747 & 15 \\
\hline & \multirow{3}{*}{ Mono-Couffo } & Male & .4515 & .05502 & 15 & .6843 & .07913 & 15 \\
\hline & & Female & .4786 & .04942 & 8 & .7339 & .09535 & 8 \\
\hline & & Total & .4609 & .05364 & 23 & .7016 & .08637 & 23 \\
\hline & \multirow{3}{*}{ Borgou-Alibori } & Male & .4606 & .16482 & 10 & .7159 & .07899 & 10 \\
\hline & & Female & .4568 & .10433 & 4 & .6705 & .08537 & 4 \\
\hline & & Total & .4595 & .14602 & 14 & .7029 & .08035 & 14 \\
\hline & \multirow{3}{*}{ Total } & Male & .4530 & .09080 & 42 & .6724 & .09833 & 42 \\
\hline & & Female & .4721 & .08289 & 23 & .6683 & .11059 & 23 \\
\hline & & Total & .4598 & .08791 & 65 & .6710 & .10199 & 65 \\
\hline \multirow{11}{*}{$\begin{array}{l}\text { Control } \\
\text { group }\end{array}$} & \multirow{3}{*}{$\begin{array}{l}\text { Atlantique- } \\
\text { Littoral }\end{array}$} & Male & .4609 & .12465 & 14 & .3771 & .04405 & 14 \\
\hline & & Female & .4990 & .08647 & 6 & .4500 & .05400 & 6 \\
\hline & & Total & .4723 & .11366 & 20 & .4089 & .04750 & 20 \\
\hline & \multirow{3}{*}{ Ouémé-Plateau } & Male & .4586 & .06821 & 6 & .4424 & .02710 & 6 \\
\hline & & Female & .4977 & .06931 & 8 & .4661 & .04178 & 8 \\
\hline & & Total & .4810 & .06914 & 14 & .4560 & .03702 & 14 \\
\hline & \multirow{3}{*}{ Mono-Couffo } & Male & .4671 & .04250 & 11 & .4278 & .04572 & 11 \\
\hline & & Female & .4591 & .06617 & 5 & .4318 & .01124 & 5 \\
\hline & & Total & .4646 & .04885 & 16 & .4291 & .03783 & 16 \\
\hline & \multirow[b]{2}{*}{ Borgou-Alibori } & Male & .4441 & .04458 & 12 & .3941 & .02217 & 12 \\
\hline & & Female & .4333 & .01515 & 3 & .4015 & .11211 & 3 \\
\hline
\end{tabular}


English Language Learning Clubs: A Novel Approach to Improving EFL Students' Verbal Communication Skills

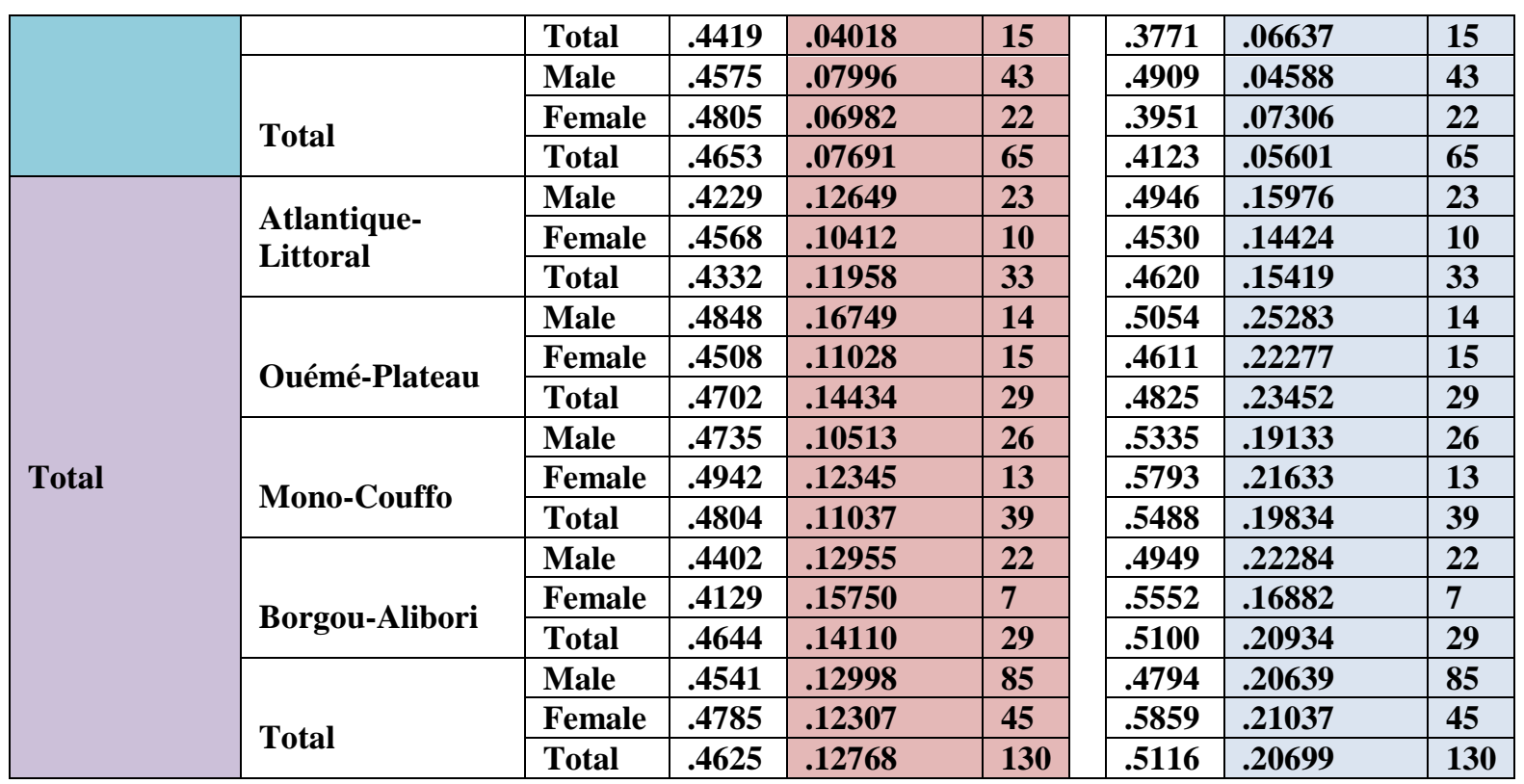

Dependent Variable: Normalised Anxiety Score

Table 3 shows a statistically significant correlation between the mean scores of learners in the experimental group and those in the control group based on the Foreign Language Anxiety pre-test $(=0.4129)$. This observation indicates that all participants in the research had about the same features regarding their degree of anxiety to speak English before installing the English-related ECA program (English Language Clubs).

The post-test results provided in Table 3 show some observable variations in the means of the two groups when the degree of anxiety is considered. Thus, when comparing the mean scores achieved by participants in the experimental group for the post-test to the mean scores gained during the pre-test, we see a significant difference in the outcomes. In comparison, when we compare the mean scores of individuals in the control group for the post-test to those for the pre-test, we see that they have stayed relatively constant.

Thus, the primary difference between the post-test and pre-test findings concerns the experimental group's learners. This difference, which was calculated using the difference in differences (DID) statistical techniques, is ascribed to the English-related ECA program (English Language Clubs) used in this research.

Table4. Estimation of the difference in differences (DID) impact of an English-related ECA program on the anxiety management of EFL learners

\begin{tabular}{|c|c|c|c|c|c|}
\hline Group & Pre-test & Post test & difference (post-test - pre-test) & t-test & p_value \\
\hline Experimental group & 0.458 & 0.691 & 0.233 & & \\
\hline Control group & 0.469 & 0.396 & -0.073 & & \\
\hline Difference & -0.011 & 0.295 & (DID) & 9.271 & 0.000 \\
\hline
\end{tabular}

\subsubsection{Results of the Analysis of the Data Collected Using the Speaking Test}

Unlike the Foreign Language Anxiety Test (FLAT) data, which were promptly calculated and examined due to their magnitude, the data from the speaking test were given in Tables $5 \mathrm{a}$ and $5 \mathrm{~b}$ on the next page before being calculated and analysed.

The learners who took the speaking test were assessed on three components of communicative competence identified by the Common European Framework of Reference (CEFR): (1) linguistic skills; (2) sociolinguistic competencies; and (3) pragmatic skills. In addition, the learners were assessed on four of the CEFR's six language competencies: (1) Grammar correctness, (2) Vocabulary Range, (3) Vocabulary Control, and (4) Phonological Control. In addition, participants in the speaking skills exam were evaluated according to their sociolinguistic appropriateness. Finally, concerning practical competency, participants were assessed on four of the six CEFR-identified pragmatic competencies: (1) Taking the floor (Turntaking), (2) Thematic development, (3) Coherence, and (4) 
English Language Learning Clubs: A Novel Approach to Improving EFL Students' Verbal Communication Skills

Spoken fluency. The interpreting score table below was created using CEFR criteria and used in determining the appropriate degree of difficulty for each test taker.

\begin{tabular}{|l|l|l|l|l|l|}
\hline Interpreting score & \multicolumn{5}{l|}{} \\
\hline & Elementary & Pre-Intermediate & Intermediate & Upper Intermediate & Advanced \\
\hline CEFR & {$[$ A1 A2 [} & {$[$ A2 B1 [} & [B1 B2 [ & [B2 C1 [ & [C1 C2[ \\
\hline Score & [0 5 [ & [5 7 [ & [7 9[ & $\mathbf{9}$ & 10 + \\
\hline
\end{tabular}

Table5a. Descriptive statistics of the speaking test from the experimental group

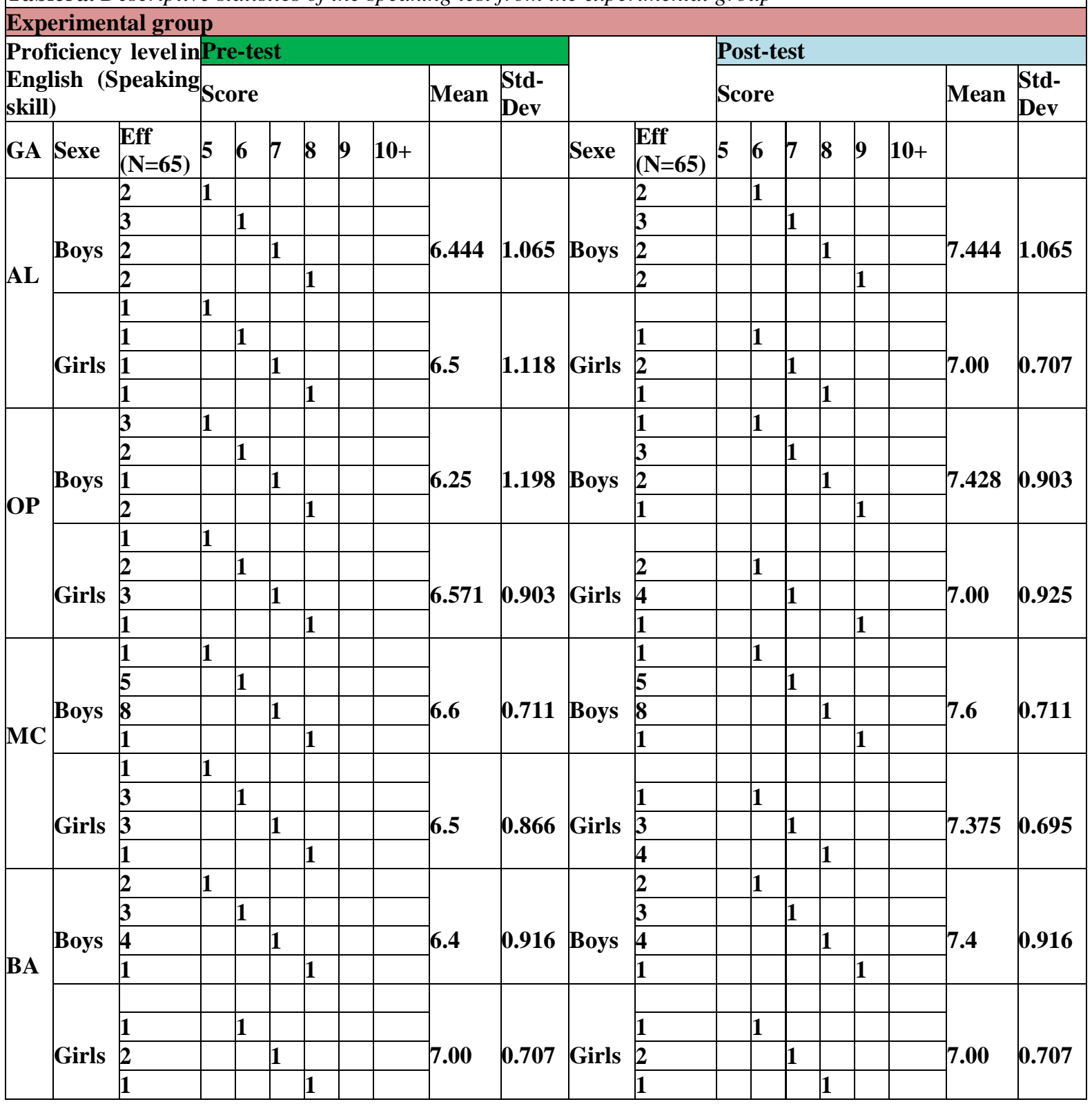

Table5b. Descriptive statistics of the speaking test from the control group

Control group

Proficiency level Pre-test

\begin{tabular}{|c|c|c|c|c|c|c|c|c|c|c|c|c|c|c|c|c|c|c|}
\hline \multirow{2}{*}{\multicolumn{3}{|c|}{ 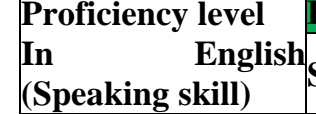 }} & \multicolumn{7}{|c|}{ Pre-test } & \multirow[b]{3}{*}{ Sexe } & \multirow[b]{3}{*}{$\begin{array}{l}\text { Eff } \\
(N=65)\end{array}$} & \multicolumn{7}{|c|}{ Post-test } \\
\hline & & & \multicolumn{5}{|c|}{ Score } & \multirow[t]{2}{*}{ Mean } & \multirow[t]{2}{*}{$\begin{array}{l}\text { Std- } \\
\text { Dev }\end{array}$} & & & \multicolumn{5}{|c|}{ Score } & \multirow[t]{2}{*}{ Mean } & \multirow[t]{2}{*}{$\begin{array}{l}\text { Std- } \\
\text { Dev }\end{array}$} \\
\hline GA & Sexe & $\begin{array}{l}\text { Eff } \\
(\mathrm{N}=65)\end{array}$ & & \begin{tabular}{|l|l}
6 & 7 \\
\end{tabular} & 78 & 9 & $10+$ & & & & & & \begin{tabular}{l|l}
6 & 7 \\
\end{tabular} & 8 & 9 & $10+$ & & \\
\hline \multirow{4}{*}{ AL } & & 2 & 1 & & & & & \multirow{4}{*}{6.5} & \multirow{4}{*}{0.823} & & 4 & 1 & & & & & \multirow{4}{*}{6.214} & \multirow{4}{*}{0.939} \\
\hline & & 4 & & 1 & & & & & & & 4 & & 1 & & & & & \\
\hline & Boys & 7 & & 1 & 1 & & & & & Boys & 5 & & 1 & & & & & \\
\hline & & 1 & & & 1 & & & & & & 1 & & & 1 & & & & \\
\hline
\end{tabular}


English Language Learning Clubs: A Novel Approach to Improving EFL Students' Verbal Communication Skills

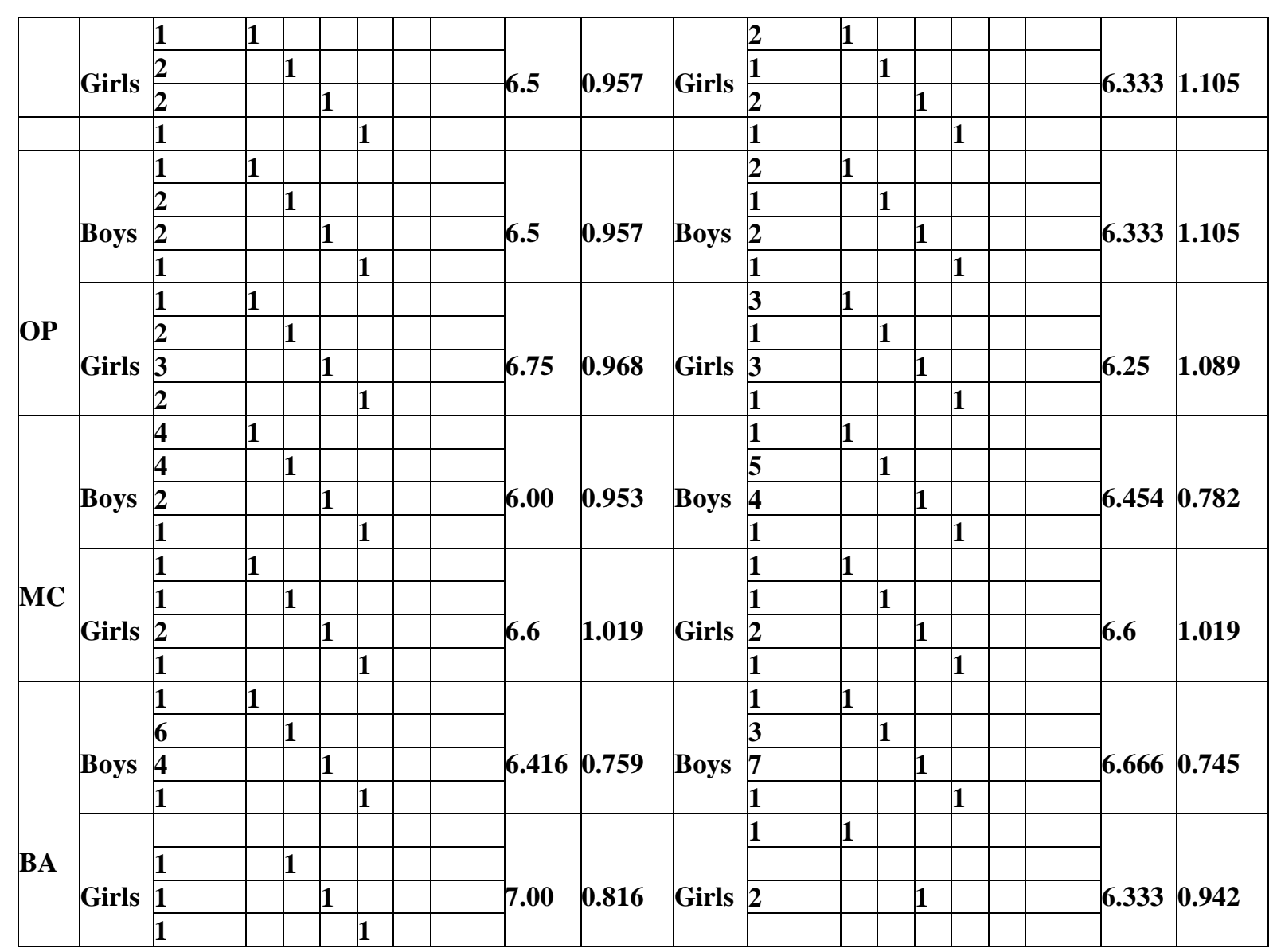

According to Tables $5 \mathrm{a}$ and $5 \mathrm{~b}$, there is no statistically significant difference between the mean scores of learners in the experimental group and those in the control group based on the results of the speaking pre-test. This observation shows that all participants in the study had roughly the same level of English competence in verbal communication ability before introducing the English-related ECA program (English Language Clubs). However, the findings in these tables show that girls' mean scores are somewhat higher than boys', regardless of whether they are in the experimental or control groups. The post-test results given in tables $5 \mathrm{a}$ and $5 \mathrm{~b}$ show that there are observable differences in the mean scores of both groups for the variable proficiency level in English or oral communication ability. In contrast to the pre-test findings, the post-test results show that the males' mean scores are more significant than the females'. One may be tempted to assert that men and women are not always equally receptive to the principles of theory and practice. Although we often claim that women are more talented than men in literary studies, the findings of this test show that males are more productive than women in practical learning situations.

When we compare the results of the means scores received by each participant in the experimental group for the post-test to the means scores acquired by each participant in the control group for the pre-test, we find a significant statistical difference. In comparison, there is no significant difference in the average scores of the control group before and after the experimentation. Therefore, the six-month training program based on English Language Clubs is a therapy whose absence has harmed members of the control group.

Comparing the post-test results to the pre-test results reveals a significant difference regarding the experimental group's learners. This difference calculated using the difference in differences (DID) statistical technique is ascribed to the English Language Clubs program, as shown in the table below.

Table 6: Difference in differences (DID) estimation regarding the effect of English-related ECA program on EFL learners' oral communication skill development

\begin{tabular}{|c|c|c|c|c|c|}
\hline Group & Pre-test & Post test & difference (post-pre) & t-test & p_value \\
\hline Experimental group & 6.512 & 7.389 & 0.877 & & \\
\hline Control group & 6.179 & 6.425 & 0.246 & & \\
\hline Difference & 0.333 & 0.963 & (DID) & 2.202 & 0.029 \\
\hline
\end{tabular}


To sum up, we can infer that the English Language Clubs experience significantly helped learners in the experimental group reduce their Foreign Language Anxiety (FLA) and develop their oral communication abilities. This inference indicates a correlation between Beninese intermediate EFL learners' involvement in English Language Clubs and their management of Foreign Language Anxiety. From this inference, it can also be noted that language-focused ECA programs, such as English Language Clubs, help improve the capacity of Beninese intermediate EFL learners to communicate in English. This outcome reveals that the current study's two goals have been achieved and corroborate the two hypotheses.

\subsection{Discussion of Results}

English is among the most significant worldwide languages, and proficiency results in increased job possibilities, income rises, and quality of life improvements. Every day, several developed and underdeveloped countries worldwide realise that their people must acquire English to stay competitive in the global economy (Malu and Smedley, 2016, p.10).

In Benin, learners' difficulties with English Language Learning are primarily attributed to their fear of speaking orally, especially in public. As a result, most of them are not engaged in authentic learning situations or exposed to the target language. Though English is a mandatory curriculum requirement for students at all levels of formal education in Benin, from secondary schools to universities, many Beninese EFL learners can hardly construct a proper sentence despite years of study.

Similarly, an examination of the responses given by the participants in this research to open-ended and closed-ended questions revealed that individuals are more anxious when confronted with public presentations and tests. Some learners experience foreign language anxiety even when they incline to study the target language. Several of them are motivated to learn their new language for academic reasons.

Additionally, the study of learners' language attitudes and answers to open- and closed-ended questions revealed that Extracurricular Activities about English language acquisition had a beneficial effect on their anxiety. Among survey respondents exposed to English Language Clubs, those with a high level of English proficiency said that they achieved it through their participation in this educational program. According to Malu and Smedley (2016, p.10), these English Learning Circles, also known as community-based English clubs, are informal meetings of learners from various communities, towns, or hamlet areas for the sole goal of practicing English. Members may be professionals or students enrolled in secondary or tertiary education. Members agree to talk in English at meetings and participate in activities that promote and promote language usage. This information can explain why all the respondents to the present study acknowledged that this out-of-school teaching program significantly facilitated them in overcoming language anxiety. They help develop the oral communication, competence in pronunciation, grammar, vocabulary, flexibility, and fluency in speaking, through their increased ability to memorise words and talk in English public. However, they have all stated that they still need practice to improve their flexibility and fluency. The fact that language learning is a time-consuming and practice-intensive process may account for this result.

English Language Clubs not only encourage top performers but also struggling students. According to Casey (2008), engaging weak pupils in the process is "powerfully motivating for [teenagers] who feel [excluded by the broader] literacy community" (p. 291). As observed by Khorsheed, Assaf, and AlDammad (2019, p.41), another tenet of influential language clubs is to be enjoyable and to provide learners greater freedom. They are usually fluid, unscheduled, participatory, and exempt learners from tests. They are primarily concerned with facilitating interactive sessions that include various activities such as oral presentations, student participation, and entertainment. Thus, they have "[...] the potential to be a powerful vehicle for motivating engaged and interested learners" along with motivating the "disengaged and frustrated" ones (Casey, 2008, p.11, as observed in Khorsheed, Assaf, and Al-Dammad (2019, p.41).

Consequently, the most effective approach to handle worry is to confront it. By taking the risk of facing one's anxiety, one may learn to control it more effectively. As is often said, it is futile to escape one's issues or worries. The best situation is to confront them. By finding the strength to face one's concerns, we may increase our chances of successfully avoiding them. Similarly, allowing learners to 
engage in language-focused Extracurricular Activity teaching programs equates them to confront their foreign language fear. By requiring children to learn from their failures and successes, they gain confidence.

Generally, the English Learning Circles program, which is usually free and voluntary, focuses on the needs and desires of learners through its learning by doing or Experiential Learning method. As observed in Zounhin Toboula (2017, p.32), it:

1. Increases the ability of learners to retain information via the use of many senses.

2. Significantly enhances leadership skills.

3. Allows incorporating a variety of teaching/learning methods into the curriculum, thus increasing creativity and flexibility.

4. Facilitates the transmission of information and abilities.

5. Focuses on learner-centered education.

6. Helps to make activities more memorable.

7. Contributes to the development of competence and confidence through the process of knowledge and solution discovery.

8. Enhances motivation for studying.

9. Increases the enjoyment of learning for both students and instructors.

10. Enables pupils to develop life skills that will be used repeatedly.

By joining English Language clubs, students who are already familiar with this learning method have the opportunity to be immersed in an environment conducive to their current level of stress or anxiety. This kind of extracurricular activity that serves as a complement to English teaching/learning is first targeted towards English majors. However, it is frequently observed that many non-English students are equally involved in searching for a relaxed atmosphere to improve their English.

Based on observations throughout learning activities during speaking class, it can be inferred that the English Club also directly promotes classroom learning (Eid and Al-Jabri, 2016, as observed in Purwanti, and Suriansyah, 2019, p.211). Furthermore, according to Pereira et al. (2013), students' involvement in English Club contributes to their ability to communicate effectively in English (As observed in Purwanti and Suriansyah, 2019, p.212).

We are all aware that we cannot learn a language without speaking it; that is why our students need to attend English Language Clubs. Several activities are used in those learning circles to help students develop their speaking, listening, and sometimes reading abilities. We have a hard time in class to practice our language, and therefore English Language Clubs are the ideal solution for those who want to overcome their anxiety and speak in public".

In summary, learning English in a French-speaking setting involves locating an environment conducive to language practice. Therefore, EFL learners must participate in English-related Extracurricular Activity programs such as English Language Clubs (ELCs) to meet individuals with a high level of language competence and who have previously had similar language problems.

By becoming English-related ECAs such as English Language Clubs (ELCs), Beninese EFL students can participate in various activities such as debates and discussions and prepared speech presentations. They can also be involved in theatrical performances and planned trips and excursions that help them improve their various language abilities. In addition, they are taught how to interact academically with their classmates or pen pals from overseas.

\section{CONCLUSION AND RECOMMENDATIONS}

English instruction is regarded as a pet peeve of many foreign language students. In Benin, one of the primary impediments to language acquisition is the fear of making errors or being misunderstood by one's peers when speaking. To address this issue, several Beninese EFL students enrol in a variety of extracurricular English study activities. English Learning Clubs are among those that offer a flexible 
and supportive learning environment for Beninese EFL learners. The current Mixed Methods study investigated the management of 130 Beninese intermediate EFL learners' anxiety and the development of their speaking skills due to their participation in various English Language Clubs to shed light on the effectiveness of such educational programs.

The findings of various analyses and interpretations indicate that after six months of participation in English Language Clubs, learners who had never been exposed to such programs improved their selfconfidence and oral communication skills. They found a new method to control their language anxiety and enhance verbal communication abilities through role-playing, observations, and active participation. A considerable number of them have pushed to adopt this educational method for foreign language acquisition and indicated that they might participate in this or similar English-related ECAs in the future. This outcome highlights the effectiveness of English-related extracurricular activities for foreign language acquisition and the efficacy of English Language Clubs in language development.

Future studies on language-related extracurricular activities should consider the methods that might be used to improve the implementation of such programs. They may also look into other creative techniques, comparable to English Language Clubs, to contribute to English teaching and learning growth. Similarly, future research might encompass longitudinal studies to elicit evidence from learners' views and beliefs about the impact of language-oriented ECA programs on their ability to control their language anxiety and improve their speaking skills. Finally, further research with a larger sample size may be conducted to determine the relationship between adopting a language-oriented ECA program in English instruction and developing intermediate EFL learners' speaking skills to help generalise the current study's findings.

\section{REFERENCE LIST}

[1] Aida, Y. (1994). Examination of Horwitz, Horwitz, and Cope's construct of foreign language anxiety: The case of students of Japanese. Modern Language Journal, 78 (2), 155- 168.

[2] Aydin, S. (2008). An investigation on the language anxiety and fear of negative evaluationamong Turkish EFL learners. Asian EFL Journal, Teaching Articles: 421-444.

[3] Bygate, M. (1987). Speaking. Oxford: oxford university Press.

[4] Campbell, H. (1973). Extracurricular foreign language activities. American Council on the Teaching of Foreign Languages, New York, N.Y.

[5] Casey, H. K. (2008). Engaging the disengaged: Using learning clubs to motivate struggling adolescent readers and writers. Journal of Adolescent \& Adult Literacy, 52(4), 284-294.

[6] Celce-Murcia, M. (1991) (ed). Teaching English as a second or foreign language. Secondedition, University of California, Los Angeles.

[7] Chan, D. Y. C., \& Wu, G. C. (2004). A study of foreign language anxiety of EFL elementary school students in Taipei County. Journal of National Taipei Teachers College, 17(2), 287-320.

[8] Cook, V. J. (2010). The relationship between first and second language acquisition revisited. The Continuum companion to second language acquisition, 137-157.

[9] Cook, V.J., Long, J., \& McDonough, S. (1979). First and second language learning. In G.E. Perren (ed.), The Mother Tongue and Other Languages in Education. CILTR, 7-22.

[10] Eid, M. I., \& Al-Jabri, I. M. (2016). Social networking, knowledge sharing, and student learning: The case of university students. Computers \& Education, 99, 14-27.

[11] Fujita, K. (2006). The effects of extracurricular activities on the academic performance of junior high students. Undergraduate Research Journal for the Human Sciences, 5(1).

[12] Ganschow, L. \& Sparks, R. (1996). Anxiety about foreign language learning among high school women. Modern Language Journal, 80 (2), 199-212.

[13] Ganschow, L., Sparks, R., Anderson, R., Javorshy, J., Skinner, S., \& Patton, J. (1994). Differences in language performance among high, average, and low-anxious college foreign language learners. Modern Language Journal, 78(1), 41-55.

[14] Hasanah, S. U. (2020). THE INFLUENCE OF JOINING ENGLISH CLUB TOWARD STUDENTS'SPEAKING ABILITY AT EIGHTH GRADE OF SMPN 1 PATIKRAJA IN THE ACADEMIC YEAR 2018/2019 (Doctoral dissertation, IAIN).

[15] Ho, J. H. (1998). Sources of second language anxiety and the benefits of instructor intervention. Kwa 
Kang Journal of TEFL, 4, 73-104.

[16] Holloway, J. H. (2002). Extracurricular Activities and Student Motivation. Educational Leadership, 60 (1): 698-713.

[17] Horwitz, E. K., Horwitz, M. B., \& Cope, J. (1986). Foreign language classroom anxiety. The Modern Language Journal, 70, 125-132.

[18] Husni, C. (2005). Comparing First and Second Language Acquisition. ENGLONESIAN. An Indonesian Scientific Journal on Linguistics and Literature. Volume 1. Number 1. ISSN 1858- 3296, pp.64-68.

[19] Khorsheed, R., Assaf, D., \& Al-Dammad, A. (2019). Effects of Creating an English Language Club on Intermediate Learners' Attitudes and Linguistic Achievement. Theory and Practice in Language Studies, 9(1), 40-44.

[20] Lazaraton, A., \& Riggenbach, H. (1991). Promoting Oral Communication Skills. In Marianne CelceMurcia (Ed), Teaching English as a Second or Foreign Language. Second Edition. University of California, Los Angeles, pp.125-136.

[21] Liao, Y. F. (1999). The effects of anxiety on Taiwanese EFL learners. The proceedings of the Eighth international symposium on English teaching (pp.453-63). Taipei: The Crane Publishing Co., Ltd.

[22] Littlewood, W. (1984). Foreign and Second Language Learning: Language acquisition researchand its implication for the classroom. Cambridge: Cambridge University Press.

[23] Liu, H. J. (2012). Understanding EFL undergraduate anxiety in relation to motivation, autonomy, and language proficiency. Electronic Journal of Foreign Language Teaching, 9(1), 123-139.

[24] Malu, K. F., \& Smedley, B. (2016). Community-Based English Clubs: English Practice and Social Change outside the Classroom. In English Teaching Forum (Vol. 54, No. 3, pp. 10-23). US Department of State. Bureau of Educational and Cultural Affairs, Office of English Language Programs, SA-5, 2200 C Street NW 4th Floor, Washington, DC 20037.

[25] Mewald C., Gassner O., Brock R., Lackenbauer F., Siller K. (2012). Testing Speaking for the E8 Standards. Technical Report 2012.BIFIE Salzburg (Hrsg.).Pp.3-61.

[26] Pereira, A. H., Ismail, K., \& Othman, Z. (2013). A model for the malaysian English language club activities. Procedia-Social and Behavioral Sciences, 90, 48-56.

[27] Purwanti, R., \& Suriansyah, A. (2019). Empowerment of 'English Club' to influence Students Achievement in Speaking. International Journal of Innovation, Creativity and Change, 5(5), Special Edition: ICET Malang City.

[28] Reva, A. (2012). The Role of Extracurricular Activities in Foreign Language Learning in University Settings. Published Master Thesis. College of Graduate Studies and Research, Department of Languages and Linguistics, University of Saskatchewan Saskatoon, Saskatchewan.

[29] Spolsky, B. (1989). Conditions for Second Language Learning. Toronto: Oxford UniversityPress.

[30] Tallon, M. (2008). A culture of caring: Reducing anxiety and increasing engagement in first-year foreign language courses. Collaborating for Student Success: Building Engagement in Learning. University of the Incarnate Word, San Antonio, TX, pp.1-20.

[31] Tallon, M. (2013). A Culture of Caring: Reducing Anxiety and Increasing Engagement in First-Year Foreign Language Courses. 2-8. [Retrieved May 7, 2014, from http://www.uiw.edu/ first year/documents/ACultureofCaring_TallonMichael.pdf].

[32] Tseng, S. F. (2012). The factors cause language anxiety for ESL/EFL learners in learning speaking. WHAMPOA-An Interdisciplinary Journal, 63, 75-90.

[33] Using SPSS and PASW. (2018, September 24). Wikibooks, The Free Textbook Project. Retrieved 09:21, June 9, 2021 from https://en.wikibooks.org/w/index.php?title=UsingSPSS_and_PASW\&oldid=3470676.

[34] Wang, Y. C. (2009). Anxiety in English language learning: A case study of Taiwanese university students on a study abroad programme. Published doctoral dissertation, University of Leeds.

[35] Zounhin Toboula, C. M. (2017). English Learning Circles: An Innovative Way to Foster Oral Communication among EFL Learners. International Journal on Studies in English Language and Literature (IJSELL) 5(3), 19-40

\section{APPENDICES / APPENDIXES}

\section{Appendix 1}

Dear...

The undersigned is carrying out a research study on the "Management of Beninese EFL Learners"e Anxiety andthe development of their speaking ability through their participation in English Language Clubs.

Please just encircle or tick the appropriate option whenever necessary. Thank you in advance for your 
cooperation.

Section One: Background information of Learners and the Perception of their Oral Proficiency

1. Are you male or female? (please encircle)

Male...

Female.

3. What is your proficiency level in English? (please encircle one only)

Beginning

Intermediate.

Advanced

5. Which of the following b

the following best describes your main 6.

reason for studying English? (please encircle one only)

Academic requirement.

Job or professional requirement

Travelling in an English-Speaking

country

Understanding the culture of English-

speaking countries

Others (please specify).

.1

2 Less than three years................

Four to six years....................2

3 Seven to nine years..................3

More than ten years.................4

4

. .5
7. How often do you use your oral English to 8 communicate?

Always.

Usually

Rarely ............................................................

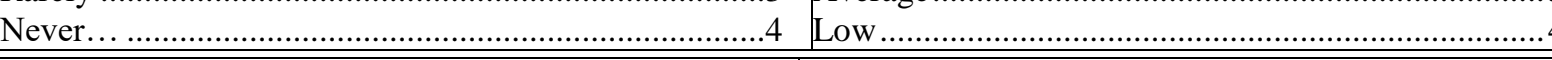

\begin{tabular}{|ll|l}
9. & Do teachers allow you toimprove your speaking skill? & 10. Do you feel satisfied with the differentspeaking activities you
\end{tabular} Always.........1 Usually .................... 2 perform in class?

Rarely................ 3 Never.......................... 4 Y Y

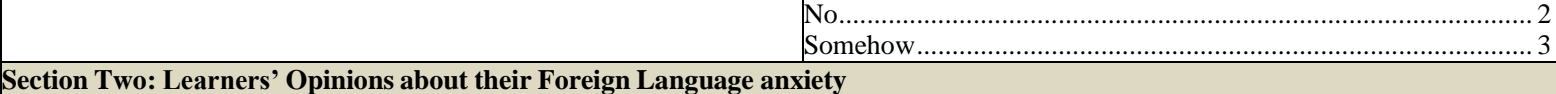

11. Have you ever experienced some anxiety when speaking or learning English as a Foreign Language?

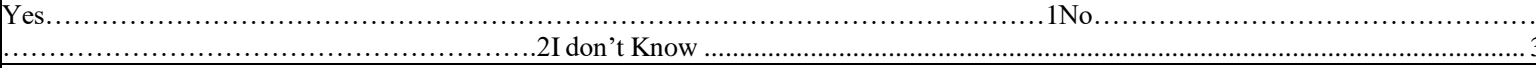

12. This question is intended to ascertain the extent to which you are anxious about foreign languages. The following statement express your attitude toward English learning. Please carefully read each statement and pick the response that best fits your circumstance, then mark if you are (Please select one for each statement)
(1)
(2)
(3)
(4)
(5)
Strongly Disagree
Disagree
Neither Agree nor Disagree
Agree
Strongly Agree

Statements

1. I never feel quite sure of myself when I am speaking English

2. I don't worry about making mistakes when dealing with English-related activities

3. I tremble when I know that I" $\mathrm{m}$ going to be called on to speak English.

3. It frightens me when I do not understand what the English speaker is saying.

4. It would not bother me at all to take more classes in English.

5. It would not bother me at all to take more classes in English.

6. When taking classes in English, I find myself thinking about things that have nothing to do with thecourses.

7. I keep thinking that the other learners are better at English than I am.

8. I am usually at ease during English tests.

9. I start to panic when I have to speak without preparation.

10. I worry about the consequences of failing my English exam.

11. I do not understand why some people get so upset over English learning.

12. When learning or practising English, I can get so nervous that I forget things I know.

13. It embarrasses me to volunteer answers to questions in a place where English is used or taught

14. I would not be nervous when speaking English with native speakers.

15. I get upset when I do not understand what someone more proficient in English is correcting.

16. Even if I am well prepared for my English classes, I feel anxious about them.

17. I often feel like not going to attend my English classes.

18. I feel confident when speaking English before people I know or in front of my mates.

19. I am afraid that my English instructor is ready to correct every mistake I make.

20. I can feel my heart pounding when I" $m$ requested to answer questions in English

21. The more I study for an English test, the more confused I get. 
English Language Learning Clubs: A Novel Approach to Improving EFL Students' Verbal Communication Skills

22. I do not feel any pressure to prepare very well for English classes.

23. I always feel that the other learners speak English better than I do.

24. I feel very self-conscious about speaking English in front of an audience or other learners.

25. English classes move so quickly that I worry about being left behind.

26. I feel more tense and nervous in my English classes than in my other types.

27. I get nervous and confused when speaking in a place where English is used or taught.

28. When I $\mathrm{m}$ on my way to attend English classes, I feel very sure and relaxed.

29. I get nervous when I do not understand every word the English instructor says.

30. I feel overwhelmed by the number of rules you have to learn to speak English.

31. I am afraid that the other learners will laugh at me when I speak English.

32. I would probably feel comfortable around native speakers of English.

33. I get nervous when the English instructor asks questions that I have not prepared in advance.

13. Which of the following activities best helps you improve your English speaking skill?

Listening to the teacher's talks and explanations......

Doing grammar exercises.

Doing vocabulary exercises

Giving oral presentations $\ldots$

Attending English-oriented Extracurricular Activities ....................................................................... 5

Section Three: Learners' Opinions about Extracurricular Activities (ECAs)

14. Are you exposed to English as a Foreign Language (EFL) outside the classroom?

Yes.

No.

15. How can you describe English Language Clubs' 16 . Does regular participation in this Extracurricular program?

Activity (ECA) help you reduce your anxiety about speaking English as a Foreign Language (EFL)?

Yes............................................................... 1

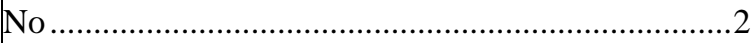

I do not Know ........................................................ 3

17. Which of the following language skills have you improved the most since the time you participated in this language-oriented Extracurricular Activity (ECA)?

Listening Skill. 1

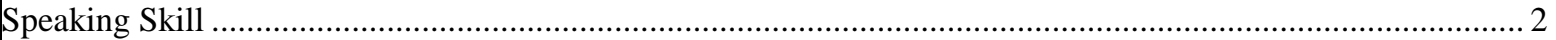

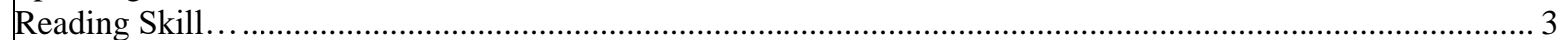

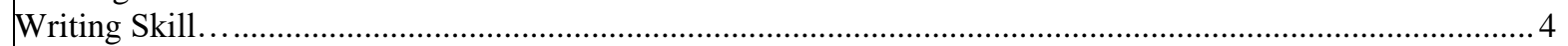

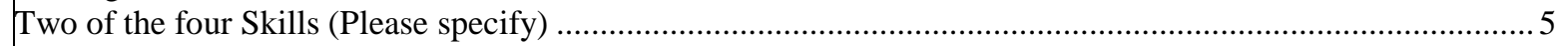

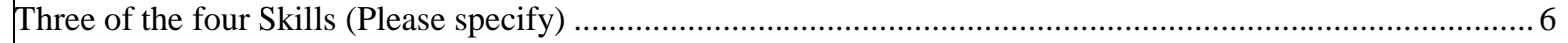

All the four skills (Listening, speaking, reading, writing) ..................................................................... 7

18. Have you noticed any impact of this ECA on your 19. Do you think that English Language Clubs are ability to speak fluently and be more motivated to studyhelpful for your English acquisition? (Please discuss English? (Please discuss $\quad$ your answer)

your answer)

20. Would you like to participate again in any of those language-oriented Extracurricular Activities(ECAs) in the future?

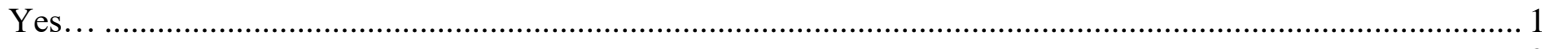

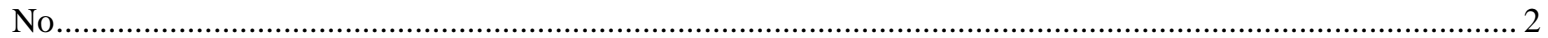

I do not Know

\begin{tabular}{|l|l} 
Thank you very much for your cooperation & \\
\hline
\end{tabular}

Appendix 2:

INTERVIEW QUESTIONNAIRE GUIDE

The same process and set of questions were used to interview all candidates.

BACKGROUND INFORMATION REVIEW

\section{Name:}

Gender:

Age: 
Proficiency level in English (Before experiencing the English Language Club teaching program):

Language skill to improve:

Reason for studying English:

Length of time of English learning:

Frequency of the use of English for oral communication (Before the ELC's experience):

\section{INTRODUCTION AND PURPOSE OF THE INTERVIEW}

\section{Introduction}

I wish you a pleasant morning/afternoon... (Interviewee's Name). My name is. and the English instructor beside me is one of my colleagues. We appreciate your willingness to volunteer for this interview session.

\section{Objective of the interview}

We're here today to discuss your English Language Club's experience since you participated in six months of oral communication courses based on the language-oriented ECA method that I pioneered with the assistance of your school's English instructor. Although you were previously asked to complete a questionnaire on this subject after that training, it is critical to collect extra information from you during one-on-one discussions. As a result, you are given a chance to affirm or modify your initial judgments about what you encountered throughout that course. Simply put, this interview aims to elicit your thoughts on the effect of this event on your English learning. As a result, my goal is not to share my viewpoint or knowledge with you. All that matters is your impressions. Therefore, you will not be permitted to respond with Yes/No or Right/Wrong. You do, however, have the right to withdraw your consent. Please feel free to express yourself.

\section{GUIDING OR EXPLORATION QUESTIONS}

1. What are your thoughts on the English Language Club's teaching methodology?

2. How would you sum up the English Language Club's educational program?

3. On a scale of 1 to 10, how would you rate your level of spoken English proficiency before participating in the English Language Club's teaching program? What is your current status (if you have improved)? Kindly include a brief remark in your response!

4. What are the advantages of this educational program?

5. How have your language abilities improved as a result of your participation in this training?

6. How has the English Language Club's teaching style affected your ability to build selfconfidence?

7. What aspects of this language-based ECA method do you like or dislike?

8. What are your current thoughts on extracurricular activities, including English?

9. What are your plans for maintaining or improving your English proficiency?

10. Include any further remarks.

\section{CONCLUSION}

Thanks a lot! We appreciate your cooperation and foresight. Your observations have been constructive.

\section{FOCUS GROUP QUESTIONNAIRE GUIDE}

\section{INTRODUCTION, PURPOSE, AND WARNING FOR THE FOCUS GROUP}

Hello, everyone! Glad to know that you have all volunteered to participate in this focus group. I know you are all busy, and I give thanks for your time.

My name is and the one next to me is my colleague.... 
The objective of the present group discussion is to evaluate your perceptions and beliefs about the impact of the English Language Club's teaching program on your English language learning. Indeed, you were previously required to complete a questionnaire form in this respect at the end of the oral communication training course in which you have been enrolled for the last six months. It is also true that some of you have all been interviewed individually about that. However, your help is still required to gather more information about the actual effect of this educational program on your English language acquisition. This group discussion will not last more than two hours.

Now may I audio-tape the discussion to make its retrospection easy? I assure you that what you will be saying will be kept secret till they are transcribed literally and destroyed.

Please note that you will not be allowed to answer by Yes/NO and Right/Wrong. However, you have the right to change your mind. So please feel comfortable speaking your mind. There will be no particularorder to have the floor. Just make sure that only one person speaks at a time. When you feel likesaying something, please just go ahead! In addition, you do not need to share the same point of view with the other members of the group.

Does anyone have anything to say before we start? (If yes, please do!) If not, then I will ask my colleague to switch on the recorder.

\section{WARMING UP OR ENGAGEMENT QUESTIONS}

First, I would like everyone to introduce himself or herself. Then, please introduce yourself to your neighbourand ask about her/his name, dream country, and hobbies.

Now I will give you two minutes to think about your most significant accomplishment in Englishspeaking since you were first exposed to the English Language Club's teaching methodology.

Something you could not do in English and that you have succeeded in doing. Is there anybody who would be willing to share their story?

\section{GUIDING QUESTIONS}

1. How can you describe the English Language Club's teaching approach?

2. How do you feel today regarding your English language learning?

3. What kind of English language skills have you improved through your participation in the oral communication classes based on the English Language Club's teaching approach?

4. What do you think about integrating the English Language Club's educational program in English classroom activities?

5. After you have experienced the English Language Club's teaching program, what are your perceptions towards English-related extracurricular activity programs in general?

6. What do you prefer or dislike the most about the English Language Club's teaching approach?

7. How confident do you feel now when it comes the time for you to speak English?

8. In addition to all we have been discussing so far, what else would you like to say concerning your English Language Club's experience?

\section{CONCLUSION}

Thank you very much for taking part in the successful focus groups. We appreciate your involvement. You will be very helpful to the study team in expressing your thoughts. The same technique and set of questions were used for all four focus groups, and the findings were the same for all four groups of participants.

\section{AUTHOR'S BIOGRAPHY}

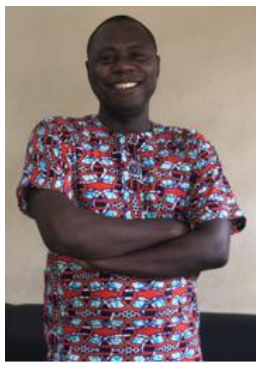

Coffi Martinien ZOUNHIN TOBOULA, is an Assistant Professor at the Department of Literature, Languages, Arts, and Communication (FLLAC) of the University of Abomey-Calavi (UAC). Holder of a Ph.D. in Linguistics and Didactics of the English language, his areas of interest are psycho-pedagogy, learner psychology, anxiety management, promotion of oral communication and leadership, promotion of extracurricular activities, and innovation of teaching and research techniques in TEFL. Competent communicator and member of Toastmasters International, he is a promoter and charter member of several English 

Communication Skills

language learning circles including the Universal Toastmasters Club of Cotonou. Freelance translator and interpreter, he is also in charge of the management of a language laboratory and passionate about writing and research in human psychology.

Citation: Coffi Martinien ZOUNHIN TOBOULA. "English Language Learning Clubs: A Novel Approach to Improving EFL Students' Verbal Communication Skills " International Journal on Studies in English Language and Literature (IJSELL), vol 9, no. 7, 2021, pp. 1-21. doi: https://doi.org/10.20431/2347-3134.0907001.

Copyright: () 2021 Authors. This is an open-access article distributed under the terms of the Creative Commons Attribution License, which permits unrestricted use, distribution, and reproduction in any medium, provided the original author and source are credited. 